\title{
Conservation Compromises: The MAB and the Legacy of the International Biological Program, 1964-1974
}

\author{
SIMONE SCHLEPER \\ Department of History \\ Maastricht University \\ Maastricht \\ The Netherlands \\ E-mail: simone.schleper@maastrichtuniversity.nl
}

\begin{abstract}
This article looks at the International Biological Program (IBP) as the predecessor of UNESCO's well-known and highly successful Man and the Biosphere Programme (MAB). It argues that international conservation efforts of the 1970s, such as the MAB, must in fact be understood as a compound of two opposing attempts to reform international conservation in the 1960s. The scientific framework of the MAB has its origins in disputes between high-level conservationists affiliated with the International Union for the Conservation of Nature and Natural Resources (IUCN) about what the IBP meant for the future of conservation. Their respective visions entailed different ecological philosophies as much as diverging sets of political ideologies regarding the global implementation of conservation. Within the IBP's Conservation Section, one group propagated a universal systems approach to conservation with a centralized, technocratic management of nature and society by an elite group of independent scientific experts. Within IUCN, a second group based their notion of environmental expert roles on a more descriptive and local ecology of resource mapping as practiced by UNESCO. When the IBP came to an end in 1974, both groups' ecological philosophies played into the scientific framework underlying the MAB's World Network or Biosphere Reserves. The article argues that it is impossible to understand the course of conservation within the MAB without studying the dynamics and discourses between the two underlying expert groups and their respective visions for reforming conservation.
\end{abstract}

Keywords: International Biological Program, Max Nicholson, Raymond Dasmann, International Union for the Conservation of Nature, Man and the Biosphere Program

Abbreviations: IBP: International Biological Program; IBP/CT: IBP's Section for the Conservation of Terrestrial Communities; ICSU: International Council of Scientific Unions; IUCN: International Union for the Conservation of Nature and Natural Resources; IUPN: International Union for the Protection of Nature; MAB: Man and the Biosphere Program (of UNESCO); SCIBP: Special Committee for the International Biological Program; UNCHE: 
United Nations Conference on the Human Environment (Stockholm Conference); UNESCO: United Nations Educational, Scientific and Cultural Organization

\section{Introduction}

For decades, science-based nature conservation, concerned with the ecological study of natural and modified systems, has been at the core of international nature protection efforts. One of the programs that can be said to epitomize this approach is the well-known and highly-successful Man and the Biosphere Program (MAB). The MAB, established in November 1971 by the United Nations Educational, Scientific and Cultural Organization (UNESCO), has been described as "pioneering" in its interdisciplinary and integrated approach to conservation, and as one of the first organizations to truly "put sustainable development into practice" (Kanie et al., 2013, p. 26; Ishwaran, 2012, p. 95; German MAB National Committee, 2005, p. 178). Within its first ten years, the MAB already involved over one hundred countries and more than ten thousand researchers working in several thousand research and training projects. Today, the MAB continues with 631 nature reserves in 119 countries, representing the world's "major biogeographical regions" (UNESCO, 1996, 2013, 2015). This World Network of Biosphere Reserves has become UNESCO's main instrument for conservation and serves as a significant platform for research, education, monitoring and demonstration.

The MAB was however not the first international conservation program to focus on the systematic protection of the world's ecosystems. Already ten years prior to the MAB's initiation, the International Biological Program (IBP) had called for a world network of reserves and in fact many former IBP conservationists moved into the MAB after the IBP's closure in 1974. Given these continuities, it is surprising how little research has been done on the MAB's intellectual origins and its links to the IBP's conservation efforts. In contrast, historiographical accounts have usually stressed the innovative novelty of the MAB's approach to conservation, for which the IBP was little more than a spark of inspiration (Chester, 2006, p. 36, Golley, 1993, p. 163, 
McCormick, 1991, p. 18, Dyer and Holland, 1988, p. 635; e.g. Di Castri et al., 1981, p. 52). ${ }^{1}$ However, a closer look at the conservation work of the IBP and contemporary controversies around it reveals its rich, so far neglected intellectual legacy for subsequent internationally organized conservation projects.

This article argues that the scientific framework of the MAB must in fact be understood as a compound of two opposing attempts to reform international conservation through the IBP. In the 1960s, high-level conservationists affiliated with the International Union for the Conservation of Nature and Natural Resources (IUCN) disputed about what the IBP meant for the future of conservation. One group of IUCN experts around the British conservationist Max Nicholson pushed for the scientific recognition of their expertise by linking conservation to the emerging field of systems ecology, using the IBP as a vehicle. At about the same time, a second group began to form at the executive center of IUCN, around the new Director General Gerardo Budowski and his Senior Ecologist Ray Dasmann. In contrast to Nicholson and his disciples, this second group based their notion of environmental expert roles on a more descriptive and local ecology of resource mapping as practiced by UNESCO. Their respective visions entailed different ecological philosophies as much as diverging sets of political ideologies regarding the global implementation of conservation. I demonstrate that the conservation methods that were finally implemented within the MAB have to be understood and studied as a compound blend of the scientific and political conceptions of conservation as brought forth by the two groups. On a general level, then, the article makes a case for studying environmental programs not as standalone achievements or successes. Rather, they should be regarded as carriers of components of diverse intellectual frameworks.

With its focus on controversies and negotiated scientific approaches in conservation, the article contributes to existing literature in both the history of nature protection and the history of science in the second half of the twentieth century. Traditionally, the historiography of conservation of this period has focused on single organizations and biographies of conservationists and has paid little attention to crossorganizational discourses at the international level (compare Schwarzenbach, 2011; Dasmann and Jarrell, 2000; Holdgate, 2003, 1999, p. 289; Holdgate, Bardeleben, 1983). The few works that have looked at

${ }^{1}$ Holdgate (1999) provides a more nuanced view of the end of the IBP and the beginning of the MAB. However, he refrains from discussing possible intellectual continuities or breaks altogether (e.g. p. 96). 
the history of ecology in conservation have focused on national academic schools and traditions (e.g. Sheail, 1998; Kingsland, 2005). Histories of global environmental thought have tried to do justice to the wide array of topics related to human concern for the environment. But often these accounts have neglected to amplify the particular relation between ideologies, politics and science (compare Bramwell, 1989; Worster, 1985). Recently, a branch of literature has sprung from the political sciences, looking at the formation of international environmental regimes. Yet works in this tradition have usually sought to explain particular policy outcomes without integrating these into the wider context of science and conservation discourses (e.g. Meyer, 2010; Meyer et al., 1997). By drawing on literature from the history of science and scientific institutions, linking ecological philosophies and the particular politics of international conservation, this paper adds another dimension to this first body of existing literature.

In particular, this article builds on those works in the history of science that have studied the roles of public intellectuals in the life sciences in the politically turbulent twentieth century (Barrow, 2013; Anker, 2001; Mitman, 1992; Kuznick, 1987). Similarly, it draws on numerous historical studies about the particular ideologies regarding the relation between man and nature that were developed by certain scientific programs or institutions (Maurel, 2013; Wöbse, 2012; Sluga, 2010; Emmerij et al., 2001). This article, however, goes beyond the national or institutional context of single organizations or academic schools that has dominated this second branch of historiography. By looking at an international scientific program, I study an expert network stretching over multiple international organizations, connecting and carrying individual experts and their ideas.

I begin by sketching the organizational and ideological background of international conservation at the beginning of the IBP. In particular, I look at the hopes conservationists attached to the program. Following this, I focus on the development of the two competing expert groups that formed around two different classification schemes designed to record and analyze ecological regions and their protection status. These two classification schemes, as I show, were built on two different ecological philosophies. Moreover, the different groups who propagated these schemes held diverging ideas on the object, methods and purposes of global conservation: their visions of conservation were linked to a particular politics of the international. Finally, I reconstruct how in the 1970s both classification schemes provided the components that would constitute the MAB's take on internationally organized and 
science-based conservation, leading to the still-existing World Network of Biosphere Reserves.

\section{Ideas for an International Program on Biology}

Ideas for a big science program in biology appealed mainly to those conservationists of the 1960s who believed that science, ecology in particular, held the key to successful nature protection. Since the 1940s, the main organization for international conservation, the International Union for the Protection of Nature (IUPN) had been referring to ecology as its scientific underpinning. Institutionally this was manifested in 1954 by the creation of a Commission on Ecology and with the employment of a first staff ecologist in the form of the Berkeley wildlife zoologist Lee Talbot. This emphasis on science-based conservation methods was accompanied by a conscious disassociation from all romanticized preservation endeavors. ${ }^{2}$ A name change to International Union for the Conservation of Nature and Natural Resources (IUCN) in 1956 proclaimed the new focus on natural resource management (Holdgate, 1999, p. 63). When in 1960, large-scale projects in Africa and Asia had brought in research grants from the National Science Foundation, IUCN's President, the Swiss zoologist Jean George Baer, proudly announced that the Union had officially been recognized as a scientific organization (Baer in IUCN, 1960, p. 22).

Despite Baer's enthusiasm, however, those conservationists who promoted science-based approaches were by no means acting in concert. IUCN lacked a common focus, a unifying idea of ecology and a consensus on how to implement conservation measures on a global scale. Within the Union different ideas circulated on the consequences that the aspired scientification should have for the content of IUCN's conservation projects. Diverging interests between those proposing a focus on ecosystems and those conservationists in the older preservationist tradition concerned with individual threatened species in particular regions, became more palpable.

Whereas ecosystem conservation was a rather young field of research, the protection of species was firmly rooted within IUCN's program. IUPN had started with the collection of data on threatened species in the 1940s. By the 1960s, the Red Data Book of Threatened

${ }^{2}$ William Cronon, for instance, has described how the echo of an unquestioning glorification of wilderness that underlay North America's early conservation movement could be heard well into the twentieth century (Cronon, 1995, p. 71; see Lewis, 2007). 
Species by the Species Survival Commission had become a cornerstone in the Union's program (Boardman, 1981, p. 51). With many former colonial regions that contained focal points for conservation moving towards independence, a number of leading IUCN conservationists saw the main area of operation of the international Union in the Southern Hemisphere. Projects such as the Union's Species Survival Commission expedition to the Near and Middle East, Africa and Asia, and its resulting report A Look at Threatened Species were part of these initiatives (Talbot and IUCN, 1960). As a consequence, and to the dismay of the proponents of ecosystem conservation, a large number of the Union's efforts focused on traditional, formerly colonial conservation areas in the African and Asian continent, which were home to charismatic animals (e.g. Adam, 2014; Tilley, 2011).

Around 1960, in the spirit of the large-scale international science programs of the time and in the climate of growing global concerns about shrinking natural resources, the first ideas for an international program for biology were developed. Conservationists of all camps within IUCN perceived this as an opportunity to enhance their recognition within the international biological community. Originally, the program was to build on advancements in the life and geo-sciences brought about by the International Geophysical Year of 1957 (Coleman, 2010, p. 2). Although the initiators behind the IBP were not conservationists, conservation experts managed to gain a foothold in the IBP's preparation process (Worthington, 1983, p. 140). ${ }^{3}$ At a planning meeting in Lisbon in 1960, IUCN's President Baer, who was acquainted with one of the Program's founders through the International Union for Biological Sciences, suggested the study of immediately threatened biological communities as one suitable topic for an International Biological Program (Waddington in Worthington, 1975, p. 4).

His proposal fell on sympathetic ears. When IBP was formally launched in 1963 at the International Council for Scientific Unions (ICSU)'s tenth General Assembly in Vienna, an international Conservation Section $(\mathrm{IBP} / \mathrm{CT})$ constituted one of seven international subcommittees. All sub-committees, subject to a central executive board, the Special Committee (SCIBP), were organized on a non-governmental

${ }^{3}$ IBP initiators were the American physicist Lloyd Berkner and the British biochemist Sir Rudolph Peters, at that time the past and the present President of International Council of Scientific Unions (ICSU), and the Italian geneticist Giuseppe Montalenti, President of the International Union of Biological Sciences (IUBS). The variety of professions indicates the unconsolidated state of transition that biology as a discipline was in at the time. 
basis (Worthington, 1975, pp. 7-8). ${ }^{4}$ They consisted of only of scientific members, a set-up that seemed to provide an opportunity for the wellnetworked conservation experts of IUCN to get involved. Yet, in contrast to Baer's original ideas, a number of conservationists in favor of ecosystem conservation on a worldwide basis hoped that the IBP would offer incentives to IUCN conservationists for reforming away from a narrow preservationist agenda.

Despite the agreement on the usefulness of an international program on biology and its relevance for conservation, uncertainties about the relation between the objectives of IBP and IUCN caused a substantial amount of friction. The undefined role that IUCN would have within IBP resulted in "considerable discussion" between Nicholson, Edward Graham, the Chairman of IUCN's Ecology Commission, Sir Hugh Elliott, the IUCN's Secretary General and Barton Worthington, the IBP's Scientific Director, regarding the sort of affiliation it should have with the IBP/CT (Nicholson, 1965a). Eventually, on October 14, 1965 the IBP/CT section, staffed with several IUCN members, published its program in the New Scientist. ${ }^{5}$ The program clearly focused on ecosystem conservation and research. At the core of the endeavor was the construction of "a world network of research reserves" (Graham, 1965, p. 127). Unlike traditional conceptualizations of national parks, this idea of a scientific network of reserves for ecosystem research was

${ }^{4}$ In total, the IBP consisted of seven sub-sections, two others on productivity of terrestrial communities and plants (PT and PP), one on each freshwater (PF) and marine productivity (PM), a section of human adaptability (HA), and a final more practically oriented section on applied biology (UM).

${ }^{5}$ Nicholson presented his sub-committee at the second IBP General Assembly in Paris in 1965. All members had some affiliation with IUCN. Amongst others, the section comprised the British Duncan Poore, Arthur Clapham, Gregory Radford, and George Peterken, Nicholson's disciples from the Nature Conservancy and the Antarctic scientist Martin Holdgate. Moreover, with Lee Talbot who had been IUCN's first staff ecologist, the Smithsonian ecologists Edward Graham and Raymond Fosberg, and the GermanAmerican botanist Dieter Mueller-Dombois, the CT section also had a strong American influence. Other well-known names included the Soviet zoologists Andrei Bannikov, the geologist Walery Goetel and the botanist Anna Medwecka-Kornas from Poland, the Ecuadorian botanist Misael Acosta Solis, and the French naturalist Jean Dorst. The Egyptian botanists Mohamed Kassas joined a few years later. Most of them had studied at renowned European or American universities, had significant field experience and could draw on extensive national and international research networks. Thus, they could provide the IBP/CT in London with the access to the relevant science communities and regions that was needed to run an international program as poorly funded as the IBP (Nicholson, 1965b). Nicholson later recalled how the IBP/CT could "exploit" IUCN's scientific network and could "work through established conservation bodies in certain countries" such as Great Britain (Nicholson in Worthington, 1975, pp. 12-13). 
clearly a move away from species- or habitat-focused conservation. Scientific investigations were presented as both the means and end to protecting such sample areas on a global scale. Conservation was to be based on ecosystem ecology and reserves were to provide areas necessary for the relevant scientific studies:

The study of natural ecosystems holds the answer to many outstanding questions in biology, both pure and applied. Such complexes, however, are being destroyed at an unprecedented rate. The Section on Conservation of Terrestrial Communities of the International Biological Programme is to work at the establishment of world-wide reserves, representing characteristic ecosystems. (Graham, 1965, p. 128)

But, for this long-term goal, IBP/CT conservationists first needed to know more about the current condition and protection status of the world's ecosystems. Basic ecosystem research was to be done. For this purpose, the IBP/CT section designed a classification and check sheet survey on the world's ecosystems. The project offered an opportunity to those conservationists within the IBP/CT and IUCN who wanted to carry out more fundamental and quantitative research into the scientific conservation of ecosystems (see Aronova et al., 2010, p. 208). At the same time, such a wide-ranging survey, unprecedented at the time, would complement the work of IUCN, and would not lead to any programmatic conflicts between the two organizations, it was hoped. At the same time.

Yet, the division among IUCN's conservationists remained. Frictions between those demanding more fundamental ecosystem research and those insisting that conservation was about threatened species soon led to the crystallization of two different groups, advocating two different classification systems and inventory methods for the IBP/CT. IUCN members affiliated with the IBP/CT began to develop their own system to identify and classify different ecosystem types around the world, which they hoped to inject into IUCN's projects at a later stage (e.g. Blair, 1977; Worthington, 1968). In this, they were however opposed by a number of IUCN conservationists, who suggested a closer cooperation with attempts to design a system for the mapping of the world's vegetation types, which were already underway at another major player dealing with aspects of global nature, UNESCO. This, they hoped, would not only solve the classification problem, but also play out beneficial for IUCN's public recognition and strengthen their institutional status within the UN system. Thus, rather than ending the 
competition for spheres of competences and the discussions on institutional relationships, the planned classification system continued to fuel differences of opinion.

\section{Nicholson and the Fosberg Classification}

In this section, I examine these differences in more detail, focusing on the development of the two classification schemes favored by two different groups of IUCN conservationists. The differences between the two classification systems, both mainly focusing on vegetation structures and both aspiring a global coverage, might look insignificant. In fact however, the two systems represented two distinct approaches to international conservation. These approaches were not only based on discrepant ecological theories. Rather, they epitomized crucial differences regarding the kind of nature they aimed to protect, the role assigned to conservation expertise, and how international nature protection was to be achieved. To grasp what was at stake, a closer look at the two sets of scientific and normative beliefs behind the classifications is necessary.

A particularly influential character behind the IBP/CT and the main promoter of its chosen classification system was the section convener, Edward Max Nicholson. Nicholson, regarding the CT section as his own brainchild, enjoyed the privilege to appoint his own section members and set in motion much of its program. Born in 1904 in Kilternan (Ireland) and perhaps one of the best-known British conservationists, he was not a biologist by training (e.g. McCormick, 1991). Having read art history at Oxford, he came to ecology through birdwatching and his extracurricular activities at the Oxford Exploration Club, which led him to meet several influential ecologists of the 1920s and 1930s: Julian Huxley, Arthur Tansley and Charles Elton. Elton's population biology had an especially strong influence on Nicholson's ecological worldview. Elton's theory of population dynamics opposed the predominant idea of a given balance in nature. Also Nicholson did not believe in a natural strife towards stability in the absence of human influences. Yet, this idea was held by many early ecologists and popular amongst a large division of conservationists who favored isolated nature sanctuaries as the main means of conservation (Cooper, 2007, p. 46). Like Elton, Nicholson thought instead that the development of local animal populations was always determined by environmental factors of their territory (Elton, 1927; see Birkhead, 2011, p. 235). The conclusion 
that managing nature by manipulating external environmental factors was not alone possible, but necessary to guarantee a balanced system was crucial to Nicholson's ecological and conservationist writings and his plans for IBP/CT.

While Nicholson learned his ecology from Elton, it was the more socialscience-oriented ecologists, Tansley and Huxley, who had a significant impact on his view on human society and man's place in nature. In contrast to Elton, who had confined his work to environmental influences on animal populations, Tansley and Huxley applied ecology to wider societal problems (Kingsland, 2005, p. 240 ff.; Anker, 2001). ${ }^{6}$ Especially his friend Huxley, who in the late 1920s had visited the USSR and had admired the results of large-scale social and economic planning, would influence Nicholson's future career and his ecological world-view. ${ }^{7}$ For Nicholson, the objective of nature conservation was essentially to distribute and manage natural resources, wild as well as farmed. In line with Tansley (1939), he saw the border between the natural and the artificial as arbitrary. In theory he distinguished between "unconverted" nature, shaped through natural selection, semi-modified areas, and natural ecosystems completely modified by man (Nicholson, 1970a, p. 64). He stressed, however, that untouched nature virtually no longer existed, neither in Great Britain nor in most other parts of the world. Accordingly, he thought that conservation approaches that pursued the mere isolation of untouched territory, without managing or researching, would contribute little to environmental problem solving (Nicholson, 1970a, p. 286).

When it came to studying and managing different landforms, Nicholson assigned a leading role to scientific experts and stressed the need for centralized scientific steering committees. ${ }^{8}$ Nicholson contin-

6 The environmental historian Peder Anker has described how in the 1920s and 1930s Tansley and Huxley, at the time good friends of Nicholson's, belonged to a particular Oxford school of human ecologists. In ecology applied to human society, this group saw the solution to the looming economic depression in Britain and other parts of the Western world (Anker, 2001). Crucial in the early work of Tansley and Huxley was a temporal, evolutionary dimension, including a diachronic account about man's relation to the Earth (Anker, 2001, p. 221). At the same time their idea of ecology also entailed an outlook to the future in which every generation was responsible to maintain the balance between man and nature for the generations to come (Tansley, 1942; Huxley et al., 1934; Huxley, 1926).

7 Nicholson's 1931 essay “A National Plan for Britain” became the manifesto of the research organization Political and Economic Planning (PEP) that he and Huxley consequently founded (Grebenik, 1955).

${ }^{8}$ In particular, Nicholson's wartime involvement strongly influenced his belief in a dominant role for scientific experts in the planning and managing of environmental and social problems (Nicholson, 1940). 
ued to follow this technocratic approach when his organizational talent granted him a post in the deputy prime minister's office in 1945 and a seat in the Official Advisory Council of Scientific Policy in 1948 (Boote, 2003). In the post-war years he contributed to the implementation of legislation such as the 1947 Town and Country Planning Act and the 1949 National Parks and Access to the Countryside Act (Boote, 2003). The acts established that "physical planning should be conceived as a national, rather than a local, responsibility" (Hill and Kerrigan, 1948) and they transferred the rights to maintain and manage the British National Parks to a national research committee. In 1952, Nicholson became Director-General of this committee, which by then had become part of the British Nature Conservancy (Bocking, 1997). ${ }^{9}$

Although successfully managing conservation in Britain through the Nature Conservancy, Nicholson's growing environmental concerns called for global solutions. Not long after the foundation of IUPN, Nicholson became involved in the activities of the organization. In the 1950s, he was a regular participant in the meetings of the Commission on Ecology and presented on his experiences relating to the exchange between ecological research and land management (IUCN, 1957, pp. 82-85). However, as a technocrat and centralist planner, Nicholson was not only discontented with the regional approach to conservation of IUCN's Special Projects, he also thought the bureaucratic management of IUCN impeded the efficient implementation of conservation expertise, and demonstrated the inconsistencies in conservation's scientific foundation (Nicholson, 1970a, p. 129, 1973; Nicholson in IUCN, 1957, p. 50). ${ }^{10}$ In the IBP's overall focus on system ecology, Nicholson saw the

${ }^{9}$ In the following years the Conservancy greatly expanded its activities and influence, establishing a large number of reserves and research sites. In 1963 it founded the Monks Wood Experimental Station not far from London, the first research laboratory to investigate the effect of toxic chemicals on wildlife (Boote, 2003). For a biography of Nicholson and a comprehensive analysis of how his political views influenced his technocratic ideas on the management and conservation of natural resources, see Mark Toogood (2008).

${ }^{10}$ Chairing IUCN's Fifth General Assembly at Edinburgh in 1956, Nicholson criticized the decision-making capacities of the Governing Council: "La véritable U.I.C.N. est l'émanation invisible de tous ceux qui demeurent attachés aux idées de la conservation et à l'écologie qui ne peut subsister si elle n'est pas renfermée dans un corps sain" (Nicholson in IUCN, 1957, p. 50). Still in 1970, he expressed dissatisfaction with the lack of inclusion of the ecological sciences in international nature conservation: "At world level, all previous efforts by the International Union of Biological Sciences and the International Union for the Conservation of Nature to interest ecologists in giving the necessary minimum support for an international working group of their own have come to nothing" (Nicholson, 1970a, p. 289). 
chance to unify once and for all the diverse theories behind conservation by devising truly global, coherent and future-oriented application principles for ecosystem conservation and management. ${ }^{11}$

In particular, computational models on energy cycles of biological systems and energy flows intrigued him (Nicholson, 1964). In the 1950s, the introduction of computers had allowed the study and simulation of functions of any system and system ecology experienced a new upswing (Hammond, 2003; Odum, 1963; Watt, 1962, p. 253). ${ }^{12}$ With the development of cybernetic approaches in ecology, studying interrelated systems consisting of life forms and their environment over time, Nicholson's demands for universal principles for conservation found a scientific basis. Computer technology was key to the new method Nicholson envisioned for conservation that went far beyond the preservation of particular species or habitats (Nicholson, 1970a, p. 59). Attributes of natural systems, he believed, could not be studied in fragments but only by looking at the functioning of the system as a whole. Systems thinking, then, constituted the necessary move away from simple, or locally-grounded, cause-and-effect thinking and shortterm planning: Problems could not be assessed or tackled locally, without taking into account the functioning of the whole system. Like the system models created for other IBP sub-projects, by, for instance, Eugene Odum (1963) or Howard Odum (1967), he commissioned a model of the biosphere and technosphere that would lay out the continuous and reciprocal interaction of human society with its environment (Figure 1). ${ }^{13}$ Nicholson thought this system approach offered a holistic outlook towards environmental problems that could back up his technocratic planning approach, linking society, land-use, and natural resource management.

11 Systems science set out to study biological systems "in which everything affects everything else." One of the earliest systems ecologists, Kenneth Watt, defined a system as "an interlocking complex of processes characterized by many reciprocal cause-effect pathways" (Watt, 1966, p. 2).

${ }^{12}$ Historians have aptly described how in the age of computer technology new ideas of system thinking merged with cybernetic calculations (see e.g. Bowler and Morus, 2005; Skyttner, 2005; McIntosh, 1986).

13 According to Keller and Golley (2000, pp. 208 ff.) energy models by, for instance, Howard and Eugene Odum played into the holistic systems thinking behind IBP in general (see Hagen, 1992, p. 167). Although not implying computation, these models emerged from the same conceptual framework as mathematical system models that calculated energy and nutritious cycles within closed ecosystems. The Odum brothers also devised models for different ecosystem types, independent of the geographical location, similar to the classification that Nicholson would develop (E. P. Odum, 1963). 


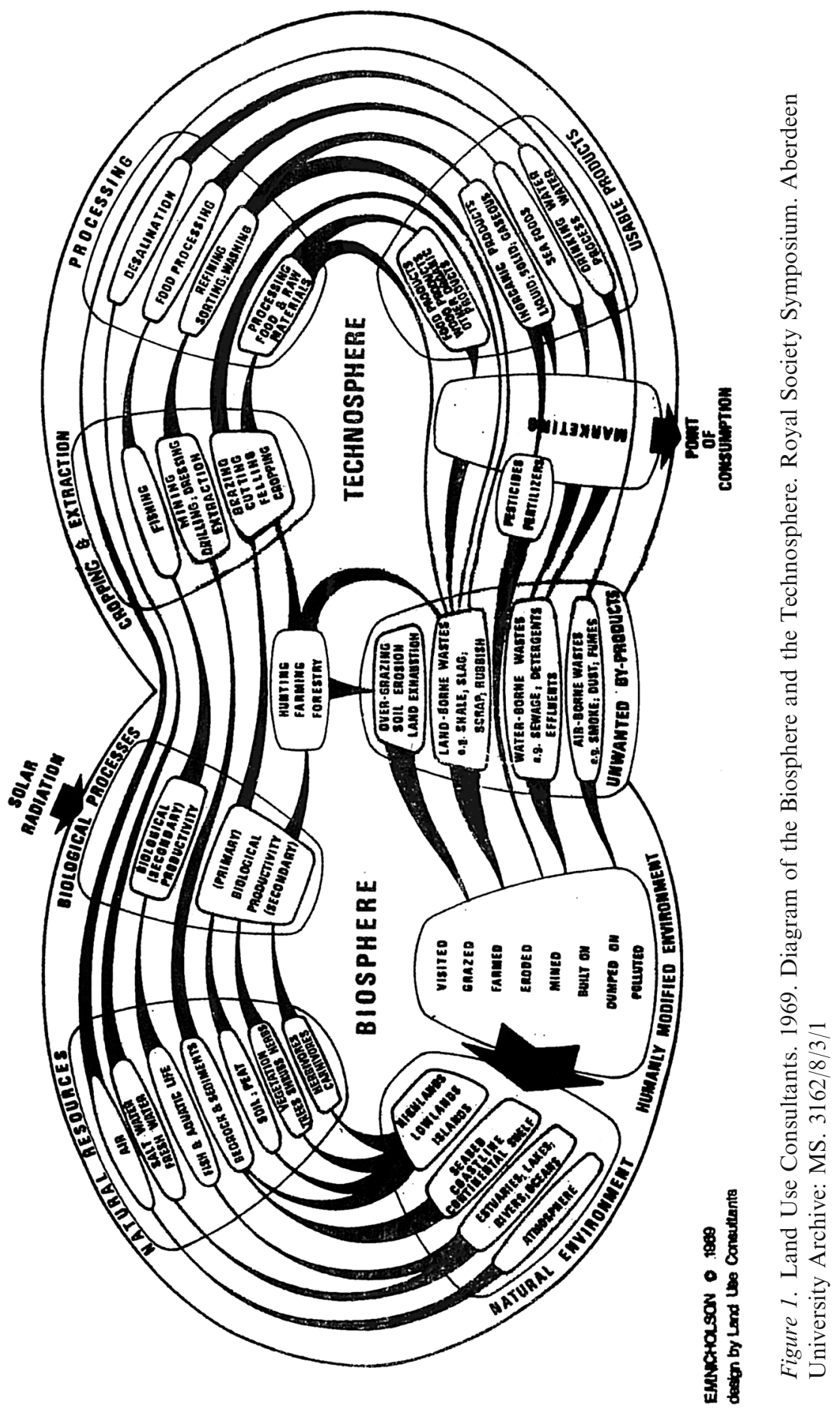


With the ideology-laden image of the technosphere and the biosphere, Nicholson illustrated the societal relevance of the work of his $\mathrm{IBP} / \mathrm{CT}$ section to audiences beyond the biological community. Midway through the IBP/CT's action phase he used the model to address development experts at the Columbia University Conference on International Economic Development, organized by economist Barbara Ward in 1970. The model allowed Nicholson to explain "nature's and man's interaction as value-free physical processes" (Nicholson, 1970b, p. 1). Designed to function as an objective tool of demonstration, it showed society and nature as part of an interdependent, yet manageable system. According to Nicholson, ecological management was needed to avoid undesirable or even disastrous side effects of humans' use of nature such as overexploitation or industrial poisoning.

Nicholson's wider philosophy remains somewhat hidden in the official IBP documents, but was made more explicit in writings he published in the same period. These contain numerous passages where Nicholson expressed his worries about the disturbed and mostly ignored relationship between nature and man and where he assigned the highest authority to a holistic, systems-based expertise:

It will not be possible to harmonise human development with the natural environment on the necessary grand scale until those in charge $[. .$.$] are educated afresh so that they learn to see problems as$ a whole. [...]. Technologists of broader and deeper formation, with complex and well-balanced professional training, will alone be capable of successfully handling the immense problems of adaption now facing us. (Nicholson, 1970a, pp. 58-59)

This passage clearly illustrates that Nicholson perceived both nature and society as interrelated entities that needed to be balanced through and managed by well-trained experts.

These key ideas - an ecosystem thinking that encompassed man within nature, future-oriented planning, and a technocratic, top-down implementation of conservation - already structured Nicholson's activities as head of the Nature Conservancy in Britain. In 1963, the British Nature Conservancy, under Nicholson's presidency, had created a survey on the human impact on the British environment. Based on the survey a chart had been created showing different land types affected in time and space, and listing land development problems as well as possible solutions. Now, as the convener of the CT section, Nicholson intended that comparable surveys should be carried out for all world regions. These surveys could help to forecast problems and to provide guidelines of 
action and protection, especially as he feared that in the future a growing world population would only intensify exploitative land-use practices (Nicholson, 1970b, pp. 3-4). In Britain, the Nature Conservancy's survey was used to inform economic decision-making on a national level. Nicholson envisioned a similar top-down approach for international development projects through conservation experts. This same line of thought was behind IBP's classification and check sheet survey of the world's ecosystems that Nicholson initiated. The design of a general ecosystem classification, coherent surveying methods, and the computerization of globally collected ecological data would bring conservation a significant step closer to becoming the superordinate science for land management that Nicholson intended it to be (Nicholson, 1969b).

Designing such a classification system, however, required epistemological choices. Nicholson was aware that a recognized way of classifying ecosystems had yet to be found. It remained unclear where one ecosystem ended and another started, and this also varied with the type and topography of the concerned area (Nicholson, 1970a, pp. 69-70). He therefore believed some pragmatic first system had to be devised to measure and reflect, "on a universal scale but on a selective manageable basis" what was necessary to understand the natural environment (Nicholson 1970a, p. 70). According to Elton, all energy production cycles within an ecosystem were based on the generation of plant material from solar energy. Therefore, vegetation could be used as a nce for ecosystem structures. ${ }^{14}$ After several rounds of discussion, the IBP/CT Section decided to use the "Classification of Vegetation for General Purposes" of the Smithsonian botanist Raymond Fosberg (1961) for the categories of the ecosystem survey they devised (Clapham, 1980, p. 91; Peterken, 1967).

In essence, Fosberg's classification (Figure 2) featured two decisive characteristics. First, it did not depend on floristic criteria, meaning in this case particular plant species. Rather it aimed to capture the physiognomic structure of the concerned ecosystem (this meant the vegetational arrangement in space: whether it was open, closed, or sparse) and the biological function of existing plant formations, for example seasonal leave shedding (Clapham, 1980, p. 38). Second, Fosberg's system was strictly based on vegetation types and purposefully avoided the incorporation of place-specific environmental information such as climatic or geographic details into the vegetation categories. This way, Fosberg's

\footnotetext{
${ }^{14}$ Nicholson concluded: "We must be content with a classification of vegetation, on the basis that vegetation is an integrated expression of the ecosystem" (Nicholson, n.d. but probably 1968). "The eventual goal will be to translate everything on to the level of entire ecosystems [...]" (Nicholson, 1969a).
} 


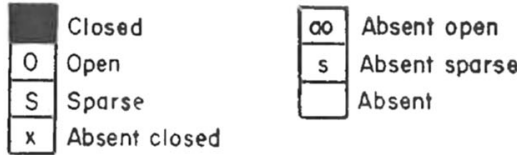

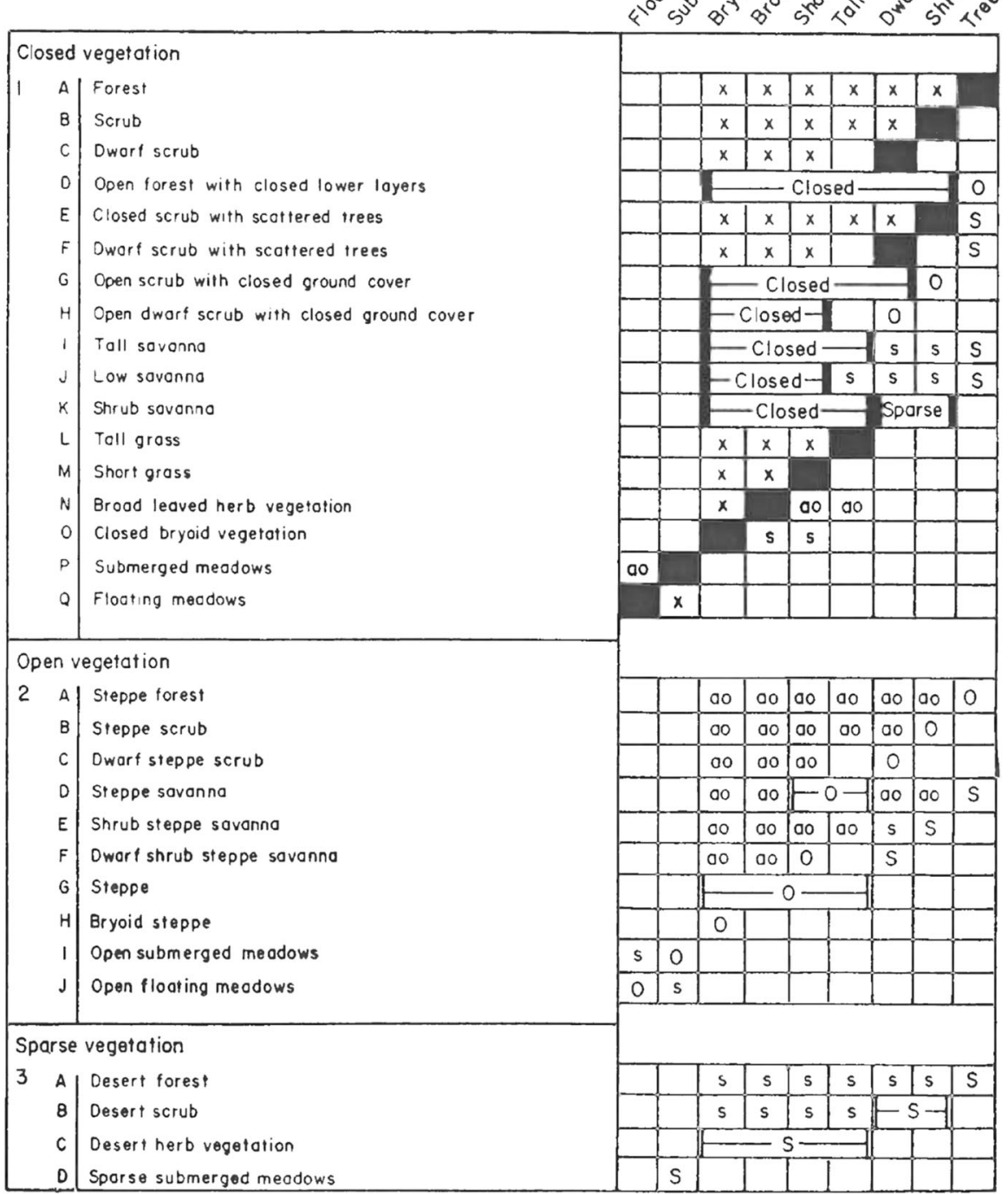

Figure 2. Fosberg's classification for the IBP/CT check sheet survey. 1980. The IBP survey of Conservation Sites: an Experimental Study, Arthur Clapham. Cambridge, UK: Cambridge University Press 
system would help to generate fundamental knowledge about the overall ecosystem, not drawing premature conclusions on its functioning from isolated elements.

Nicholson believed this approach to be advantageous for two reasons. On the one hand, as it was not bound by local species occurrences, he believed the Fosberg system could be employed to study ecosystems anywhere on the globe. On the other hand, the check sheet survey based on Fosberg's classification could be used to do ecological groundwork beyond conservation in the strictest sense. Nicholson hoped that a separate recording of vegetation information and other environmental data would eventually allow for objective research on the relations between climate, structure, and flora. Nicholson explained the importance of collecting data in "pure" form

so that any subsequent attempts to correlate e.g. vegetation occurrence with soil or climate will be entirely free of the suspicion that the method of collecting data contains a built-in bias towards assuming some type of connection [between, for instance, climate, region, and vegetation] which should be the function of the data to test objectively. (Nicholson, 1969b) ${ }^{15}$

Eventually, Nicholson hoped, the separated data units, recorded on a check sheet, paired with a worldwide grid square nce system and stored in a punch card database at Monks Wood, could instruct the anticipatory scientific planner. In line with Elton's population dynamic principles, Nicholson believed that the organization and structure of biotic communities in different habitats was in fact very similar (Nicholson, 1969b; compare Cooper, 2007, p. 45). The data of the check sheet survey would not only make basic information available to study the functioning of ecosystems and to determine different types of natural systems. It would moreover enable future computer calculations on the potential productivity of different plant and land type combinations. Nicholson saw the purpose of the check sheet survey and the classification in enabling future scientists to forecast which crops, and later also which animals, could potentially prosper where (Nicholson, 1970a, pp. 68,73). Throughout the years of IBP and its synthesis until 1974, Nicholson was optimistic that this kind of ecological studies would reform global conservation and land-use practices, coordinated by his team at Monks Wood (Nicholson in Clapham, 1980, p. 2).

\footnotetext{
15 "Where vegetation units are delimited in part by environmental features, correlation of such a vegetation map to environmental maps of the same area becomes problematic as this may result in circular reasoning" (Clapham, 1980, p. 38).
} 


\section{The UNESCO Classification}

A few years after Nicholson had begun to plot his ambitious reform plans for international conservation standards, a competing group of IUCN conservationists recognized in IBP's Conservation Section the chance to link conservation more strongly to UNESCO. UNESCO had been one of the original sponsors of IUCN in 1948 and, since then, it had developed a strong and financially secure resource research program to which several IUCN conservationists hoped to link their own projects. Already in 1960, UNESCO had regrouped its activities in the division for the Studies and Research relating to Natural Resources, under the engineer and Director General Michel Batisse. Conservation featured alongside studies on hydrology, geology, soil science, and other ecological studies. The program, which started its operational phase parallel to the IBP launch in 1964, had at its disposal an attractive budget of nearly US $\$ 800,000$ for the first 2 years alone, a substantial sum compared to the US\$200,000 yearly available on average for all IBP projects together (Worthington, 1983, p. 165). Its Advisory Committee consisted of fifteen internationally-known specialists, many of whom were also members of IUCN. Like Nicholson and the IBP/CT also UNESCO emphasized the importance of integrated surveys and maps of natural resources on land and water. Likewise, UNESCO also stressed the need for international cooperation when it came to the use of natural resources.

While IBP was in full swing, this focus on international cooperation in resource research led to the UNESCO Biosphere Conference in 1968 and first discussions about Man and the Biosphere Program (MAB) in 1970 (UNESCO, 2006, pp. 225-228). The MAB, which could potentially take over the IBP's results after 1974, offered an outlook to a new and attractive platform for conservation expertise. In the late 1960s, a group of former UNESCO biologists had found its way in at the top end of IUCN. These conservationists were now hoping that their many colleagues working for IBP could, after its potential integration into MAB, facilitate a closer alliance between IUCN and the resource-rich UNESCO (UNESCO, 1970).

On first sight, UNESCO's emphasis on natural resources maps seemed to complement the aims of Nicholson and his Conservation section. Furthermore, the scientific board of IBP saw cooperation as a great chance to assure secure funding for IBP in general, and from the mid-1960s, closer links developed between the ICSU and UNESCO. However, at a closer look UNESCO's classification was grounded in a different ecological phi- 
losophy and an idea on conservation expertise opposite to that by Nicholson's Conservation Section. UNESCO's approach was however shared by several high-ranking IUCN conservationists. The group, amongst them also IUCN's Director General Gerardo Budowski and the Union's Senior Ecologist Raymond Dasmann, lobbied for a stronger affiliation of the IBP/CT's work with research on natural resources conducted by UNESCO. Both Budowski and Dasmann, who both had formerly worked for UNESCO, viewed Nicholson's attempts to turn the IBP/ CT into a prototype for global, conservation-steered ecosystem management with some skepticism. ${ }^{16}$ Their critique was substantiated by the classification system which they used to oppose that of Fosberg.

As indicated, IBP/CT promoted global ecosystem studies that focused on potential productivity. It aimed at recording separate data units, which would allow for supposedly objective computer surveys for productive land-management. In contrast, UNESCO's classification was more descriptive. It was neither suited nor aimed for computer calculations but aimed at the mapping of resources for human use. It was not to be used for a globally comparative survey, but was to serve for the creation of sets of local maps for particular resource projects. Published in 1973 by the UNESCO Committee on Classification and Mapping of the World's Vegetation the UNESCO's vegetation classification was based on a list supplied by Josef Smithüsen and Heinz Ellenberg, and further drafts by Ellenberg and Dieter Mueller-Dombois from 1967 and 1969 (UNESCO 1973a; Ellenberg and Mueller-Dombois, 1967). It provided sets of symbols, color schemes and labels to mark vegetational zones on geographical regions or country maps with a scale of 1 to 1 million.

Unlike the Fosberg system, the UNESCO classification system was not a tool to advance basic ecological research. The authors did not assume that physiognomy and structure of the vegetation alone could identify types of ecological habitats or environments. Therefore, the UNESCO classification added supplementary terms referring to climate, soil and landform, believed to coincide in particular geographical

16 In 1966, the American population biologist Dasmann had been suggested to UNESCO by the American conservationist Russell Train, at the time Vice President of the WWF's US branch and President of the North American Conservation Foundation. At UNESCO, Dasmann was to write the background papers for the Biosphere Conference of 1968. At the Conference, the take-over of the IBP by the MAB was first discussed (Dasmann and Jarrell, 2000, p. 58). The Venezuelan agronomy and forestry expert Gerardo Budowski had been UNESCO's Program Specialist for Ecology and Conservation between 1967 and 1970. In 1970 Budowksi, IUCN's new Director General, invited his former UNESCO colleague Dasmann to join IUCN's staff. 
197 V.C.5a

\begin{abstract}
Tropical alpine open to closed bunch-grass communities with a woody synusia of tuft plants (Espeletia, Lobelia, Senecio), microphyllous to leptophyllous dwarf-shrubs and cushion plants, often with woolly leaves. Above timberline in low latitudes: Páramo and related vegetation types without snow in the alpine regions of Kenya, Colombia, Venezuela, etc.
\end{abstract}

Figure 3. UNESCO's classification units. 1973a. International Classification and Mapping of Vegetation, UNESCO. Paris: UNESCO

conditions. Instead of first testing these links, like Nicholson hoped to do with the IBP/CT check sheet survey, Ellenberg and Mueller-Dombois added assumed climatic information to the categories and definitions of the classification (UNESCO, 1973a; Clapham, 1980, p. 42). Additionally, the UNESCO classification contained categories which combined environmental, vegetational, and floristic (species-specific) data (Figure 3). It linked more structural elements to particular associations of indicator species which Ellenberg called "ökologische Gruppen" or "synusia" (Ellenberg, 1963; Clapham, 1980, p. 93). ${ }^{17}$ Based on these, an accompanying vegetation map included a color and symbol code for 225 vegetation types, in order to provide a general overview that could serve for immediate statistical purposes (Figure 4). This way, for example, endangered vegetation units in different regions could be singled out for conservation on a map.

For IUCN's senior ecologist Dasmann and others at IUCN, the UNESCO's system, combining environmental, formation and particular species information into one category, was preferable over IBP/CT's strict separation of recorded characteristics. Basic research into ecosystems or predicting potential productivity was not what they aimed for. The synthesis volume on CT's work later described that many conservationists recognized from the beginning that the "information derived from the use of the Fosberg classification would be insufficient for the full purposes of the check sheet survey, with its emphasis on conservation" (Clapham, 1980, p. 67). In particular Dasmann displayed his discontent when corresponding and publishing on the matter. The focus of conservation, after all, was on threatened species and populations and not on physiognomic formations (Dasmann in Clapham, 1975). Knowledge over formations was insufficient for conservation purposes according to Dasmann, as areas with similar physiognomic features could have a very different species configuration (Dasmann, 1973a, b). With this view he was not alone. Also former

${ }^{17}$ One example can be found in Figure 3: “"Tropical alpine to closed bunch-grass communities with a woody synusia of tuft plants' (Espeletia, Lobelia, Sencio)." 
TRE ES

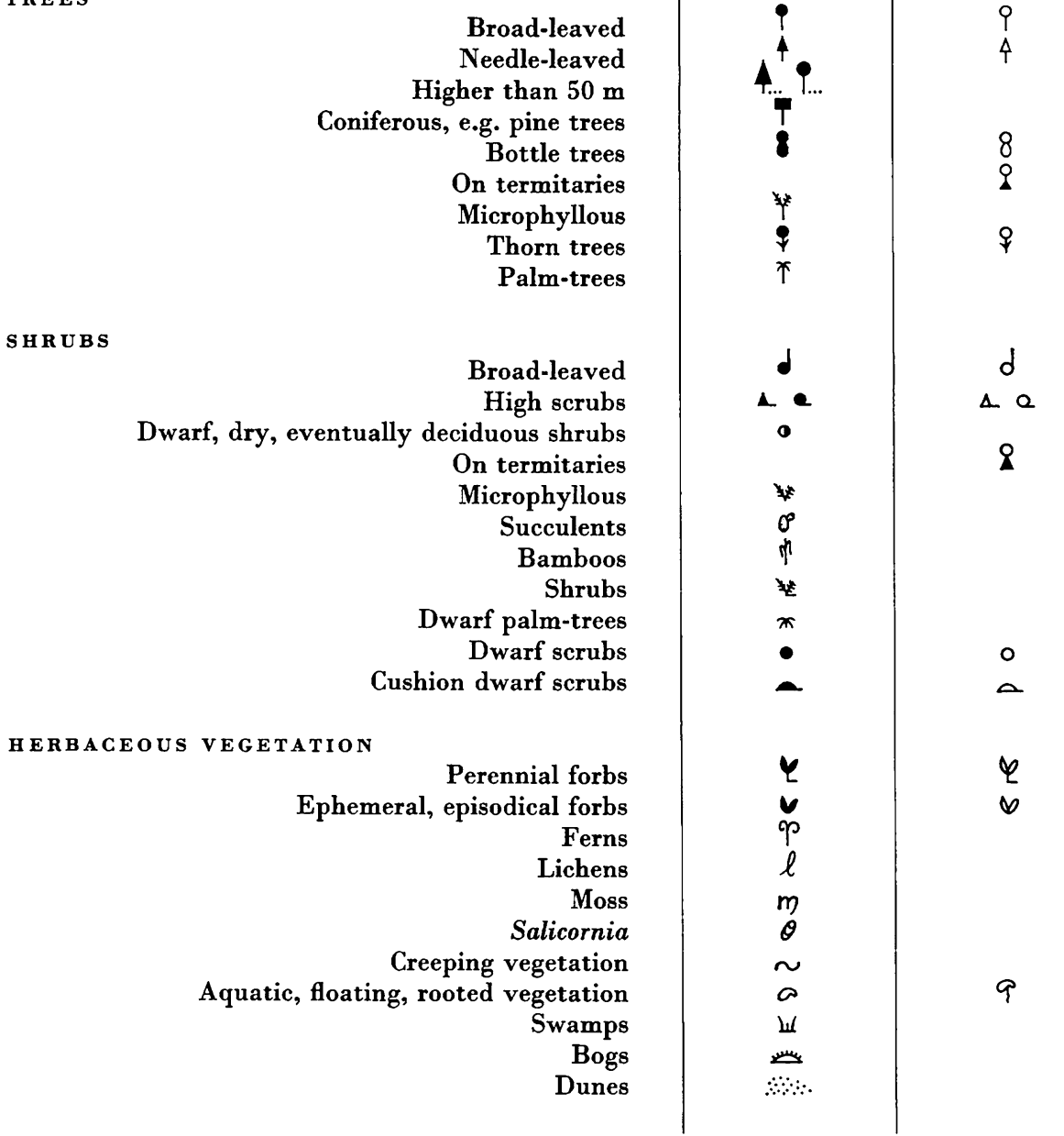

Figure 4. UNESCO's vegetation symbols. UNESCO 1973a. International Classification and Mapping of Vegetation, UNESCO. Paris: UNESCO

IUCN conservationist Duncan Poore explains retrospectively that he disagreed with an inventory approach, such as Nicholson's, that focused on long-term data collection and calculations of productivity, and which neglected the focus on threatened species and ecosystems necessary for conservation (Poore in Norman, 2014). In particular, the "predictive power" that Nicholson assigned to the check sheet survey was criticized, as it was believed to do little to solve the pressing conservation problems of the time (Fosberg, 1972). 
Rather than striving for universal categories, the information conveyed through the UNESCO maps was directly applicable for local conservation purposes. At the same time, it was relevant for those purposes only. First of all, the maps were restricted to 'unspoiled' vegetation. In contrast to Nicholson's project of mapping all types of managed and unmanaged ecosystems, the UNESCO classification was based on natural climax vegetation and near-climax vegetation, "not wheat fields," or "banana plantations" (UNESCO, 1973a, p. 16). Moreover, rather than imposing universally valid criteria from London or the Smithsonian Institute to be disseminated throughout all world regions, the system was much more open to local approaches: "Specific mapping criteria may have to be worked out regionally within this framework. These can then be based on a combination of regionally significant structural and floristic criteria" (Clapham, 1980, p. 43). Also local knowledge and language could be taken into account: "Locally established terms meaningful to the inhabitants of the respective region (e.g. campo cerrado) may be added [...]. In this manner vegetation maps are meaningful to local users as well as to a world-wide audience. This is especially important for comparative studies" (UNESCO, 1973a, p. 29).

Here we see very different politics of global conservation at work. UNESCO's mapping system reflected their take on conservation expertise, which had - unlike Nicholson's doctrinal universalism - always allowed for regional approaches and initiatives. The conservation issues that UNESCO had so far been concerned with included programs on arid lands and the humid tropics and had aimed at giving advice for particular localities, which aligned well with Dasmann's own experiences (Küchler, Maquin, and UNESCO, 1970; also see UNESCO, 2006). Critical of all forms of centralized technocracy, he considered undifferentiated topdown approaches unworkable when the diverse values and priorities of local communities, regions or nation states were at stake (Dasmann, 1965, p. 292, 1968, pp. 223 ff.): "No single piece of legislation or governmental reorganization will guarantee that environmental conservation will become a reality. [Environmental struggles] will be found at city, county, state, national, and international levels" (Dasmann, 1972a, p. 433). Neither in conservation, nor in development issues could experts "impose something from without" (Dasmann and Jarrell, 2000, p. 47).

In contrast to the IBP, Dasmann and those favoring closer links between IUCN and UNESCO stressed not only the common duties of its member states to carefully gauge projects of resource use and conservation. UNESCO pointed at the countries' own rights to locally determine development rates, allowing for more bottom-up conserva- 
tion incentives. ${ }^{18}$ The IBP/CT's cybernetics was supposed to provide an object analysis of the biosphere-technosphere-nexus, allowing for topdown management measures that were society independent and value free. In Dasmann's vision, to the contrary, society and man constituted the determining factor, both in the organization and the content of conservation. Moreover, Dasmann began to doubt that the same universal rules for conservation could apply everywhere on the globe. From the mid-1970s onwards, he would propagate a form of "bioregionalism" that linked nature protection to local traditions and cultures (Pepper et al., 2003, p. 237). Measurements should not be "filtered from the top", but designed and implemented "at grass root level", respecting the "importance of indigenous peoples and their cultures" (Dasmann, 1975, pp. 48, 154). Thus, Dasmann's vision for conservation and conservation expertise was not only irreconcilable with Nicholson's central technocratic planning, but was inherently anthropocentric and put a lot of emphasis on fieldwork, a diversity of methods, as well as local experiences and governance.

In line with Dasmann's more inclusive way of thinking, a number of IUCN members remained in favor of integrating the IBP more closely into the UNESCO program, to allow for a continuation of IBP efforts after the end of its ten-year period (Holdgate, 1999, p. 98). On an InterAgency Consultation Meeting at UNESCO in 1969, it was decided that the "structures created through IBP, the international networks amongst scientists, need[ed] to be kept alive" and should be integrated into UNESCO's Man and the Biosphere Program after the closure of IBP around 1972 (UNESCO, 1970). In 1971 an International Cooperation Council was formed with representatives from UNESCO, IUCN and the IBP to facilitate this process. It was to ensure that the follow-up of the IBP entailed a stronger alignment with UNESCO's focal areas, the study of particular ecosystem types and climatic regions in particular locations, as well as a much stronger human-centered approach to conservation.

\section{The Legacy of the IBP}

At a first look, it seems as if reform ideas outpaced those of Nicholson. The IUCN expert group around Dasmann, promoting an alliance with UNESCO's Rational Use of Natural Resources Program was better equipped than the IBP's Conservation Section. A look at the three main

18 Also several UNESCO advisors found fault with the IBP's omission to integrate experts and interests of developing countries in their projects (Maurel, 2013, p. 185). 
outcomes of the MAB's first 5 years as reported by the Secretary of the MAB's International Coordination Council, nicely serves to demonstrate the main differences between the future for the IBP/CT as Nicholson had envisioned it, and the course that the actual work of the MAB took (Di Castri, 1976, p. 235). These differences were wideranging, encompassing the objectives, methods as well as the administration of planned conservation projects.

First, the endeavors of the MAB were supposed to be problem-oriented. Instead of continuing the scientific groundwork as Nicholson had hoped, MAB focused on practical programs in developing regions. In the 1970s, the MAB programs diversified, focusing more narrowly on particular ecological regions. By 1981, MAB researchers had established a network of seventeen complementary pilot projects on land-use in the humid tropics. The pilot projects mainly dealt with natural ecosystems, human impact, resource use strategies and social and biological processes (Di Castri et al., 1981, p. 53).

Second, the units chosen for study programs had to be "comprehensive" and "based on human use systems" (Di Castri, 1976, p. 235). This not only included local terminology, but also a focus on acute societal problems. The ecological approach followed by MAB was significantly different from the encompassing systems approach promoted by IBP. UNESCO's MAB, with its anthropocentric approach, was opposed to a true systems approach that looked first at the whole system, regarding man and his environment in interdependence. MAB, in its studies on particular ecosystems, continued and extended UNESCO's research in arid and tropical zones (Golley, 1993). ${ }^{19}$ These regions were considered of particular development interest. Proposals by the US national IBP Committee for a Program for the Analysis of World Ecosystems (PAWE), to counterbalance MAB's work on particular regions, were steadfastly rejected (Blair, 1977, p. 147).

And third, the MAB's projects, mainly taking place on a national level, were supposed to fall under the shared responsibility of natural scientists, social scientists, as well as administrative decision-makers. This multi-disciplinary composition differed from Nicholson's hopes for an overarching ecological approach encompassing nature and society. After the decision to continue the running projects of the IBP with the

19 The MAB consisted of fourteen major themes: "Man's interaction with terrestrial, freshwater and coastal ecosystems, from polar to tropical zones excluding oceanic systems; natural coastal ecosystems, form polar to tropical zones excluding oceanic systems, natural ecosystems, and systems under various stage of manipulation, transformation and degradation; and large urban systems, considered as ecosystems" (Di Castri et al., 1981, p. 52). 
framework of the MAB, Nicholson's ideal of a non-governmental, mostly Northern conservation elite, that would be able to advise environmental measures top-down, was not possible within the political framework of UNESCO. After the closure of the IBP, international conservation expertise was to be mainly allocated on the basis of international representation (Worthington, 1983). Moreover, in contrast to Nicholson's technocratic approach, the MAB put emphasis on local participation. As an UN Special Agency program, projects were encouraged to be locally implemented with the involvement of social scientists, land use planners, resource managers and local populations, integrated into each country's local culture (Di Castri et al., 1981, p. 54; M'Bow, 1981, p. 5).

It would be wrong to conclude, however, that the IBP/CT's work remained unrecognized by the future members of the MAB. Despite the divergence from Nicholson's original plans, the IBP/CT contributed to the conceptual framework of the MAB to a substantial degree. In fact, the conservation methods that were implemented within the MAB constituted a blend of both the scientific and political conceptions of conservation promoted by Nicholson and those of his opponents. This merging of approaches became most visible in discussions on the usefulness of the two classification schemes and the IBP/CT check sheet survey after the IBP's closure.

In 1972, IBP/CT began its synthesis and the evaluation of its check sheet survey. The UNESCO classification, in contrast, remained a theoretical construct until much later. The number of returned check sheets was smaller than expected, but significantly nonetheless, for the first time a global ecological survey had been conducted. The results were collected at the Nature Conservancy's research station at Monk's Wood by IUCN member and Nicholson disciple George Radford. ${ }^{20}$ Paired with a respective geo-code that informed on the geographical origins of the results, the data resulting from the survey was stored first on punch cards and later on magnetic tapes to be used with early ATLAS 2 computers (Clapham, 1980, p. 116). The computer system, then, could provide responds to inquiries on the characteristics of the vegetation at particular sites, on the location of particular vegetation structures, and on additional climatic, species, and conservation related information that had been recorded (Clapham, 1980, p. 115). In this form, the recorded data from the check sheet survey was available to the

${ }^{20}$ In 1972, the check sheet survey had brought in data from about 2000 check sheets that IUCN could operate with (IUCN, 1972, pp. 51-52). 
MAB's expert panel concerned with designing a program for conservation (UNESCO, 1973b).

The extensive networking that Nicholson and his section practiced during the years of the IBP ensured that a great majority of the IBP conservationists remained influential in international conservation after the IBP's closure (Blair, 1977, p. 138). Also MAB's Expert Panel concerned with conservation included Nicholson's supporter Radford of the CT section's outpost at Monks Wood, as well as Worthington of the IBP's central office in London. Throughout the report of the expert panel one finds traces of the IBP/CT's conceptual framework and its work. The report turned the ecosystem-based biosphere reserves into the main tool for conservation. Previously, this had not been part of UNESCO's research programs on natural resources (UNESCO 1973b, pp. $20 \mathrm{ff}$; compare UNESCO, 1963). ${ }^{21}$ Moreover, the expert panel recognized the value of check sheet survey (UNESCO, 1974). At the Third Session of the International Coordination Council in 1974, the Council's members stressed that the information gathered during the check sheet survey should be taken into account when selecting new nature reserves or designing new conservation projects within the MAB (UNESCO, 1974, p. 3).

Whereas the tangible results of the Survey were much appreciated, the Fosberg classification that underlay the Survey's design remained somewhat contested within the MAB expert panel. One of the classification's early critics, Dasmann, too, was a member of the panel. Not content with the physiognomic approach of Forsberg's classification, Dasmann had begun to develop an adapted version of the UNESCO classification that assigned an even more dominant role to indicator species (Dasmann, 1972a, pp. 248-249). For this he drew on the ideas of the American plant ecologist Frederic Clements and zoologist Victor Shelford, who believed that ecosystems, in successions, always tended towards a stable climax state with a predictable constellation of characteristic species (Dasmann, 1973b, p. 1; Clements and Shelford, 1939). Ecosystems' climax states in different world regions - so-called "biomes"-were much alike, containing similar flora and fauna, Clements and Shelford proposed. ${ }^{22}$

${ }^{21}$ In the meantime, ecosystems thinking had gathered momentum also outside the IBP. The expert panel's report of 1973 not only mentions the work of Nicholson's intellectual role model Elton, it also explicitly refers to the Odums' work on nutrition cycles (UNESCO, 1973b, p. 11).

${ }^{22}$ In 1943, Dice had developed a similar concept, so-called "biotic provinces" that Dasmann used as interchangeably with the idea of biomes (Dice, 1943). 
This way of ordering nature was in several ways opposed to Fosberg's classification and Nicholson's interpretation thereof. First of all, climax states as described by Clements and Shelford only occurred in virtually untouched ecosystems, remote from human settlements. Secondly, different from the Fosberg-based check sheet survey, the mapping of biomes, presupposing the dominance of certain species in particular regions, and would not generate any new knowledge on potential combinations of species, climate and land types that in could contribute to more an efficient land use planning and management. Yet, for Dasmann, Clements's and Shelford's biomes presented an excellent starting point to develop regional maps of the major habitats that might require conservation (Dasmann, 1972b, p. 251). The successional status of a biome province was already determined by the types of species it contained. For mapping, classification, and most of all for conservation purposes, Dasmann proposed to classify biomes in a way that directly distinguished these on the base of the distinct fauna and flora they contained (Dasmann, 1972b, pp. 249-250). Thus, when in 1973 the MAB expert panel called together a task force to draw up a list of criteria and guidelines for the establishment of the MAB's biosphere reserves network, MAB members actually had three classifications at their disposal (UNESCO, 1973b).

In the end, the task force called for a classification that could combine the results of the CT survey and Dasmann's new classification (UNESCO, 1974). The result was yet another classification, published in 1975 by the Hungarian biologist and biogeographer Miklos Udvardy on behalf of UNESCO. This system still forms the decision framework for biosphere reserve nominations today (UNECSO, 2013). Although the Fosberg system, at the time, was regarded as an approximation rather than a final system, the Udvardy classification system certainly benefitted from the trials and errors of the IBP's check sheet survey (UNESCO, 1974, p. 50; Clapham, 1980, p. 26 ff.; see Mueller-Dombois, 1984). The original authors of both the UNESCO and the IBP/CT classification, Ellenberg and Fosberg, contributed to the drafting of Udvardy's system. They took over parts of the basic structure of Dasmann's classification, but subordinated the biomes to larger biogeographical realms and provinces. These differed in their geographical location, yet also in their main physiognomy, resembling Fosberg's categories, and together they constituted the global system that Nicholson had aspired (Udvardy, 1975, p. 13). Information on fauna and flora were thought essential for conservation purposes, yet featured in lower sub-categories to be filled in by local experts (Udvardy, 1975, pp. 13-15). The protection of endangered species was one of the aims 
behind the classification, however ecosystem research, the "necessary basis for further development of the life sciences," was deemed a goal equally important (Udvardy, 1975, p. 5).

\section{Conclusion}

This article has looked at two competing conceptualizations of international conservation expertise that emerged in the 1960s and 1970s. From the beginning of the IBP in 1964, IBP/CT convener Max Nicholson attempted to reform international conservation by strengthening and consolidating its scientific basis and by broadening its sphere of competences to scientifically planned land-use practices. After 1970, a second group of conservationists around IUCN's Senior Ecologist Ray Dasmann tried to use the IBP to develop a closer cooperation with UNESCO. Both groups saw their view on conservation as global and science-based. The case of the IBP shows, however, that for each group this entailed very different ideas on the objectives and practices associated with conservation work and expertise.

Yet, the differences in the two groups' political ideas, organizational cultures and ecological philosophies did not lead to the eventual exclusion of one approach by the other. Rather than continuing a single conservation traditions, the MAB emerged from the interaction of the two groups, combining parts of IBP/CT's ecosystems approach with an emphasis on local action and intergovernmentally distributed expert roles as promoted by UNESCO-friendly conservationists.. Since 1975, the MAB has been combining ecosystems research for land use management with the targeted combat of local conservation problems. It has created a global network of reserves for conservation, research, monitoring and education. Now, this scheme links up exising reserves and research efforts around the globe, connecting conservation and ecosystem ecology in practice. While focusing on traditional UNESCO regions, such as arid lands and the humid tropics, this Biosphere Reserve Program draws links between natural and modified ecosystems. Its reserves contain zones for research on natural ecosystems, experiments on productivity, and for economic activities (UNESCO, 2013; 2015). This way, the MAB has answered Nicholson's call for a global conservation regime composed of reprehensive samples of the world's ecosystems (UNESCO, 1974, p. 50). Moreover, it has extended UNESCO's ecosystem studies from the purely natural to the human-influenced and built environment, in line with Nicholson's British 
experiences (Golley, 1993). At the same time, a global network of local projects with particular foci has emerged under the overarching umbrella of studying natural systems and their human usage. Up to today, the MAB's World Network of Reserves Program integrates elements of both Nicholson's universal approach to conservation and of the regionally focused conservation projects, called for by his original adversaries such as Dasmann.

On a more general level, the story of the IBP and its continuation in UNESCO's MAB shows how the study of different ecological philosophies and concomitant conservation approaches can contribute to a better understanding of environmental decision making as a compromise. So far, it has mostly been controversy and dispute that has brought the environmental field to the attention of the media and scholarly investigation (see Rowland, 1973; Dryzek and Schlosberg, 2005; Sabin, 2013). ${ }^{23}$ Yet, in policy-oriented international working groups or expert councils, negotiation prevails over conflict. When decisions have to be made, there is often the need to draw from the various intellectual resources available. Recorded conflicts between sentimental nature lovers and resource exploiters, techno-pessimists and promoters of economic growth have done little to help us understand the workings of experts in the environmental field. In practice, the formulation of environmental advice and guidelines is an on-going process during which problems, expertise and methods are continuously mediated and adjusted. Outcomes are seldom the result of just one 'winning' group of experts. Only by studying how constellations of arguments evolve, correlate and interact we can, therefore, understand how scientific expert roles and discourses on environmental problem solving emerge and consolidate.

\section{Acknowledgments}

The article draws on several unpublished collections, including the Edward Max Nicholson papers at the Special Collections Centre of

${ }^{23}$ Rowland describes the debate between advocates of the society managing approach supported in Paul Ehrlich's Population Bomb (1968) and the anti-population planning critique of Barry Commoner's The Closing Circle (1971) and which would culminate in a public dispute in 1972 at the UN Conference on the Human Environment (UNCHE). Covering forty years of debates about the environment, Dryzek and Schlosberg (2005) draw attention to the diversity of opinions represented within environmental politics. Sabin (2013) recounts how in the 1970s and 1980s techno-optimistic economists like Julian Simon challenged the warnings of Ehrlich's that predicted resource scarcity and famine if no action was taken against the looming perils of human overpopulation. 
The Sir Duncan Rice Library at the University of Aberdeen, the Edward Max Nicholson Papers at the Linnean Society Archives, the Edward Max Nicholson Papers at the Royal Geographical Society Archive, as well as the SCIBP Papers at the Royal Society Archives. My work there has been supported by several individuals, in particular by Gina Douglas, Michelle Gait, and Lady Jennifer Norman. As part of my PhD research at Maastricht University, this article builds on numerous meetings with my supervisors Raf de Bont and Ernst Homburg. An earlier draft has been presented at the Modern Science Working Group at the Department for the History of Science at Harvard University and has benefited from the valuable comments by Janet Browne, Everett Medelsohn, Alex Czizar, Zoe Nyssa, and Geert Somsen. I thank the two anonymous reviewers for their constructive criticism. This work is part of the research program Nature's Diplomats, which is financed by the Netherlands Organization for Scientific Research (NWO).

\section{Open Access}

This article is distributed under the terms of the Creative Commons Attribution 4.0 International License (http://creativecommons.org/licenses/by/4.0/), which permits unrestricted use, distribution, and reproduction in any medium, provided you give appropriate credit to the original author(s) and the source, provide a link to the Creative Commons license, and indicate if changes were made.

\section{References}

Adam, Rachelle. 2014. Elephant Treaties: The Colonial Legacy of the Biodiversity Crisis. Hanover: University Press of New England.

Anker, Peder. 2001. Imperial Ecology: Environmental Order in the British Empire, 1895 1945. Cambridge, MA: Harvard University Press.

Aronova, Elena, Baker, Karen, Oreskes, Naomi. 2010. "Big Science and Big Data in Biology: From the International Geophysical Year through the International Biological Program to the Long Term Ecological Research (LTER) Network, 1957Present." Historical Studies in the Natural Sciences 40(2): 183-224.

Barrow, Mark. 2013. "Naturalists as Conservationists: American Scientists, Social Responsibility, and Political Activism before the Bomb." Garlad E Allen, Roy MacLeod (eds.), Science, History and Social Activism: a Tribute to Everett Mendelsohn. Rotterdam: Springer Netherlands, pp. 217-233.

Birkhead, Tim. 2011. The Wisdom of Birds: An Illustrated History of Ornithology. London: Bloomsbury. 
Blair, Frank. 1977. Big Biology: The US/IBP. Stroudsburg: Dowden, Hutchinson \& Ross.

Boardman, Robert. 1981. International Organization and the Conservation of Nature. London: Macmillan.

Bocking, Stephen. 1997. Ecologists and Environmental Politics: a History of Contemporary Ecology. New Haven: Yale University Press.

Boote, Robert. 2003. "Obituary: Max Nicholson. The Prime Mover of the Nature Conservancy and the World Wildlife Fund, Who Helped Inspire Nature Reserves and Ecological Research." The Guardian. Accessed 10 December 2014.

Bowler, Peter and Morus, Iwan. 2005. Making Modern Science: A Historical Survey. Chicago: University of Chicago Press.

Bramwell, Anna. 1989. Ecology in the 20th Century: A History. New Haven: Yale University Press.

Chester, Charles. 2006. Conservation Across Borders: Biodiversity in an Interdependent World. Washington, DC: Island Press.

Clapham, A. Roy. 1975. "Letter to Geoffrey Radford," September 24. Royal Society Archives: NHM, Box 12, Folder 9.

1980. The IBP Survey of Conservation Sites: an Experimental Study. Cambridge: Cambridge University Press.

Clements, Frederic and Shelford, Victor E. 1939. Bio-Ecology. New York: Wiley.

Coleman, David. 2010. Big Ecology: The Emergence of Ecosystem Science. Oakland, CA: University of California Press.

Commoner, Barry. 1971. The Closing Circle: Nature, Man, and Technology. New York: Knopf.

Cooper, Gregory. 2007. The Science of the Struggle for Existence: on the Foundations of Ecology. Cambridge: Cambridge University Press.

Cronon, William. 1995. Uncommon Ground: Toward Reinventing Nature. New York: W.W. Norton \& Company.

Dasmann, Raymond F. 1965. Environmental Conservation, 1st ed. London: Wiley.

1968. A Different Kind of Country. London: Macmillan. 1972a. Environmental Conservation, 3rd ed. London: Wiley.

- 1972b. "Towards a System for Classifying Natural Regions of the World and their Representation by National Parks and Reserves." Biological Conservation 4(4): 247 255.

- 1973a. Classification and Use of Protected Natural and Cultural Areas: A Report Prepared within the IUCN Secretariat. Morges: IUCN.

— 1973b. A System for Defining and Classifying Natural Regions for Purposes of Conservations: a Progress Report. Morges: IUCN.

— 1975. The Conservation Alternative. London: Wiley.

Dasmann, Raymond F., and Jarrell, Randall. 2000. Raymond F. Dasmann: a Life in Conservation Biology. Santa Cruz: UC Santa Cruz Regional History Project, University Library.

Di Castri, Francesco. 1976. "International, Interdisciplinary Research in Ecology: Some Problems of Organization and Execution. The Case of the Man and the Biosphere (MAB) Programme." Human Ecology 4(3): 235-246.

Di Castri, Francesco, Hadley, Malcom, and Damlamian, Jeanne. 1981. "MAB: The Man and the Biosphere Program as an Evolving System." Ambio 10(2/3): 52-57.

Dice, Lee R. 1943. The Biotic Provinces of North America. Ann-Abor: University of Michigan Press. 
Dryzek, John, Schlosberg, David. 2005. Debating the Earth: The Environmental Politics Reader. Oxford: Oxford University Press.

Dyer, M. I., Holland, M. M. 1988. "UNESCO's Man and the Biosphere Program." BioScience 38(9): 635-641.

Ehrlich, Paul. 1968. The Population Bomb. New York: Ballantine Books.

Ellenberg, Heinz. 1963. Vegetation Mitteleuropas mit den Alpen, in kausaler, dynamischer und historische Sicht. Suttgart: E. Ulmer.

Ellenberg, Heinz, Mueller-Dombois, Dieter. 1967. Internationales Biologisches Programm: IBP; Beiträge der Bundesrepublik Deutschland. Bad Godesberg: Deutsche Forschungsgemeinschaft.

Elton, Charles. 1927. Animal Ecology. Chicago: University of Chicago Press.

Emmerij, Louis, Jolly, Richard, and Weiss, Thomas. 2001. Ahead of the Curve? UN Ideas and Global Challenges. Bloomington: Indiana University Press.

Fosberg, F. Raymond. 1961. "A Classification of Vegetation for General Purposes." Tropical Ecology 2(1-2): 1-28.

— 1972. "Letter to Gina Douglas," January 18. Royal Society Archives: NHM, Box 12, Folder 1.

German MAB National Committee, ed. 2005. Full of Life: UNESCO Biosphere Reserves - Model Regions for Sustainable Development. Berlin: Springer.

Golley, Frank. 1993. A History of the Ecosystem Concept in Ecology: More Than the Sum of the Parts. New Haven: Yale University Press.

Graham, Edward. 1965. "A World Network of Research Reserves." New Scientist 28: $127-129$.

Grebenik, Eugene. 1955. "World Population and Resources." The Political Quartlery 26(4): $371-379$.

Hagen, Joel. 1992. An Entangled Bank: the Origins of Ecosystem Ecology. New Brunswick: Rutgers University Press.

Hammond, Debora. 2003. The Science of Synthesis: Exploring the Social Implications of General Systems Theory. Boulder: University Press of Colorado.

Hill, Harold, Kerrigan, Daniel. 1948. The Town and Country Planning Act, 1947. London: Butterworth.

Holdgate, Martin. 1999. The Green Web: A Union for World Conservation. London: Earthscan.

2003. Penguins and Mandarins: Memories of Natural and Unnnatural History. Spennymoor: The Memoir Club.

Holdgate, Martin and Bardeleben, Angelika. 1983. Umwelt-weltweit: Bericht des Umweltprogramms der Vereinten Nationen (UNEP) 1972-1982. Berlin: Schmidt.

Huxley, Julian. 1926. The Stream of Life. London: Watts.

Huxley, Julian, Barlow, H, Dalmahoy, Thomas, and Blackett, Patrick. 1934. Scientific Research and Social Needs. London: Watts \& Co.

Ishwaran, Natarajan. 2012. "Science in Intergovernmental Environmental Relations: 40 Years of UNESCO's Man and the Biosphere (MAB) Programme and its Future." Environmental Development 1(1): 91-101.

IUCN. 1957. Proceedings and Papers: Fifth General Assembly at Edinburgh in June, 1956. London: Society for the Promotion of Nature Reserves in collaboration with the Nature Conservancy for the IUCN.

1960. Proceedings of the Seventh General Assembly, Warsaw 1960. Brussels: IUCN. 1972. 1972 IUCN Yearbook. Annual Report of the International Union for the Conservation of Nature and Natural Resources for 1972. Morges: IUCN and UNESCO. 
Kanie, Norichika, Haas, Peter, Andresen, Stainer, et al. 2013. "Green Pluralism: Lessons for Improved Environmental Governance in the 21st century." Environment: Science and Policy for Sustainable Development 55(5): 14-30.

Keller, David and Golley, Frank. 2000. The Philosophy of Ecology: From Science to Synthesis. Athens, GA: University of Georgia Press.

Kingsland, Sharon. 2005. The Evolution of American Ecology, 1890-2000. Baltimore: Johns Hopkins Press.

Küchler, August, Maquin, Montoya, and UNESCO. 1970. The UNESCO Classification of Vegetation: Some Tests in the Tropics. Turrialba:Instiuto Interamericano de Ciencies Agricolas.

Kuznick, Peter. 1987. Beyond the Laboratory: Scientists as Political Activists in 1930's America. Chicago: University of Chicago Press.

Lewis, Michael (ed.). 2007. American Wilderness: A New History. Oxford: Oxford University Press.

Maurel, Chloé. 2013. "L’Unesco, un pionnier de l'écologie ? Une préoccupation globale pour l'environnement, 1945-1970." Monde(s): Histoire, Espaces, Relations 30(1): 171-192.

M'Bow, Amadou-Mahtar. 1981. "Man and the Biosphere." The UNESCO Courier 34(4): 4-5.

McCormick, John. 1991. Reclaiming Paradise: The Global Environmental Movement. Bloomington: Indiana University Press.

McIntosh, Robert. 1986. The Background of Ecology: Concept and Theory. Cambridge: Cambridge University Press.

Meyer, Jan-Henrik. 2010. "Saving Migrants: A Transnational Network Supporting Supranational Bird Protection Policy." Wolfram Kaiser, Brigitte Leucht, and Michael Gehle (eds.), Transnational Networks in Regional Integration: Governing Europe, 1945-1983. Basingstoke: Palgrave Macmillan, pp. 176-198.

Meyer, John, Frank, David, Hironaka, Ann, Shofer, Evan, and Tuma, Nancy B. 1997. "The Structuring of a World Environmental Regime, 1870-1990." International Organization 51(4): 623-651.

Mitman, Gregg. 1992. The State of Nature: Ecology, Community, and American Social Thought, 1900-1950. Chicago: University of Chicago Press.

Mueller-Dombois, Dieter. 1984. "Classification and Mapping of Plant Communities: a Review with Eemphasis on Tropical Vegetation." G. M. Woodwell (ed.), The Role of Terrestrial Vegetation in the Global Carbon Cycle: Measurement by Remote Sensing. Chichester: Wiley.

Nicholson, E. Max. 1940. How Britain's Resources are Mobilized. Broadbridge Alderley: Clarendon Press.

— 1964. Conservation and the Next Renaissance. The Horace M. Albright Conservation Lectureship, IV, (Berkeley, California, March 4, 1964). Berkeley: University of California Press.

1965a. "Letter to Jean George Baer," June 15. Linnean Society Archives: EMN/ IBP, Box "Relation with IUCN 1963-1972."

1965b. "IBP Section CT/Conservation of Terrestrial Communities Progress Report for the Sectional Committee," Royal Society Archives: NHM, Box 1.

n.d., but probably 1968. "International Selection of Areas for Reserves," University of Aberdeen Special Collections: MS. 3162. 
1969a. "For the Record," January 23, sent to Gerardo Budowski, Raymond Fosberg, Duncan Poore and Heinz Ellenberg on January 24, Royal Society Archives: NHM, Box 13, Folder 10.

- 1969b. "Letter to Heinz Ellenberg," January 24. Royal Society Archives: NHM, Box 13, Folder 10.

1970a. The Environmental Revolution: A Guide for the New Masters of the World. London: Penguin Books, Limited.

1970b, "Environment." Columbia University Conference on International Economic Development. New York Sessions at Columbia University-February 20-21, 1970. Ann Arbor: University of Michigan Press. Linnean Society Archives: EMN/IBP, Box 4, Folder 9 (ii).

— 1973. The Big Change: After the Environmental Revolution. New York: McGrawHill.

Norman, Lady Jennifer. 2014. "Conservation with Dr. Poore," email sent to Simone Schleper on March 13, 2014.

Odum, Eugene P. 1963. Ecology. New York: Holt, Rinehart and Winston.

Odum, Howard T. 1967. "IBP Symposium: Environmental Photosynthesis." Science Science 157(3787): 415-416.

Pepper, David, Webster, Frank, and Revill, George. 2003. Environmentalism: Critical Concepts. London: Routledge.

Peterken, George. 1967. "Letter to Ray Fosberg," January 27. Royal Society Archives: NHM, Box 12, Folder 9.

Rowland, Wade. 1973. The Plot to Save the World: the Life and Times of the Stockholm Conference on the Human Environment. Toronto: Clarke, Irwin.

Sabin, Paul. 2013. Paul Ehrlich, Julian Simon, and Our Gable over Earth's Future. New Haven: Yale University Press.

Schwarzenbach, Alexis. 2011. Saving the World's Wildlife: WWF-The First 50 years. London: Profile Books.

Sheail, John. 1998. Nature Conservation in Britain: The Formative Years. London: The Stationery Office.

Skyttner, Lars. 2005. General Systems Theory: Problems, Perspectives, Practice. Hackensack: World Scientific.

Sluga, Glenda. 2010. "UNESCO and the (One) World of Julian Huxley." Journal of World History 21(3): 393-418.

Talbot, Lee, and IUCN. 1960. A Look at Threatened Species: A Report on Some Animals of the Middle East and Southern Asia which are Threatened with Extermination. London: Fauna Preservation Society for IUCN.

Tansley, Arthur. 1939. The British Islands and Their Vegetation. Cambridge: Cambridge University Press.

- 1942. The Value of Science to Humanity. The Herbert Spencer Lecture, Oxford University, 2 June 1942. Crows Nest: Allen \& Unwin.

Tilley, Helen. 2011. Africa as a Living Laboratory: Empire, Development, and the Problem of Scientific Knowledge, 1870-1950. Chicago: University of Chicago Press.

Toogood, Mark. 2008. "Beyond 'the Toad Beneath the Harrow': Geographies of Ecological Science, 1959-1965." Journal of Historical Geography 34(1): 118-137.

Udvardy, Miklos. 1975. A Classification of the Biogeographical Provinces of the World, 8 vols. Morges:International Union for Conservation of Nature and Natural Resources. 
UNESCO. 1963. "The Conservation of Nature and Natural Resources in Ethopia: Report by Julian Huxley, Theodore Monod, L. Swift, L., and Edward B. Worthington," UNESCO/NS/NR/47., Accessed 18 May 2015. http://unesdoc.unesco. org/images/0013/001398/139892eb.pdf.

- 1970. "Inter-Agency Consultation Meeting on the Long-Term Programme Based on the Outcome of the Biosphere Conference, 23 and 24 March 1969," Royal Society Archives: NHM, Box 72.

1973a. International Classification and Mapping of Vegetation. Paris: UNESCO Publishing.

1973b. Expert Panel on Project 8: Conservation of Natural Areas and of the Genetic Material they Contain: Final Report. Paris: UNESCO Publishing.

1974. Task Force On: Criteria and Guidelines for the Choice and Establishment of Biosphere Reserves: Organized Jointly by UNESCO and UNEP. Paris: UNESCO Publishing.

- 1996. Biosphere reserves: The Seville Strategy and the Statutory Framwork of the World Network. Paris: UNESCO Publishing.

2006. Sixty Years of Science at UNESCO, 1945-2005. Paris: UNESCO Publishing. 2013. Biosphere Reserve Nomination Form. Paris: UNESCO Publishing.

2015. "Man and the Biosphere Programme." Accessed 18 May 2015. http://www.unesco.org/new/en/natural-sciences/environment/ecological-sciences/manand-biosphere-programme/.

Watt, Kenneth. 1962. "Use of Mathematics in Population Ecology." Annual Review of Entomology 7(1): 243-260. 1966. Systems Analysis in Ecology. New York: Academic Press.

Wöbse, Anna-Katharina. 2012. Weltnaturschutz. Umweltdiplomatie in Völkerbund und Vereinten Nationen 1920-1950. Frankfurt am Main: Campus Verlag.

Worster, Donald. 1985. Nature's Economy: a History of Ecological Ideas. Cambridge: Cambridge University Press.

Worthington, Edward B. 1968. "IBP: International Goals." Science 161(3839): 313-314. — 1975. The Evolution of IBP. Cambridge: Cambridge University Press.

1983. The Ecological Century: A Personal Appraisal. Broadbridge Alderley: Clarendon Press. 